\title{
Non-deliverable forwards - factors of development and market structure
}

\author{
Nierzeczywiste transakcje terminowe - czynniki rozwoju i struktura rynku
}

\section{Introduction}

Non-deliverable forwards (NDFs) are foreign exchange derivatives traded in the over-the-counter (OTC) market. A derivative is a contract between two or more parties whose value is derived from the value of an underlying asset, which typically changes in value following changes in an underlying variable - for example foreign exchange rate, interest rate, commodity or share. Derivatives allow business entities to hedge their exposure to risks by entering into contracts whose value moves in the opposite direction of entities' existing financial risks (Campbell, Mauler \& Pierce, 2019). While derivatives can be effective and efficient tools of hedging, they are also well suited for speculative purposes (Bartram, 2019). Speculative trading is one of the main reasons for significant increase in the use of derivatives over the last decades. Depending on the underlying asset, different kinds of derivatives can be distinguished. One of the oldest financial derivatives are those based on foreign exchange rates. While a significant body of work has been devoted to currency derivatives, such as deliverable forwards, options, futures and swaps, non-deliverable forwards have not been the focus of research to such an extent. Most studies concentrated on Asian NDF markets, which results from the biggest development of those markets. This is supported by Schmittmann \& Teng (2020) who said that NDF markets in major Asian currencies are large, grow rapidly, and often exceed onshore markets in transaction volume. The main focus of research is relationship between deliverable forward, NDF and spot markets. Schmittmann \& Teng (2020) found that the changes in NDF prices affect onshore forward markets and vice versa. According to Ma, Ho \& McCauley (2004) the Asian NDF volatility is generally larger than the spot 
counterpart, owing in some measure to official intervention in the spot market. Misra \& Behera (2006) studied the NDF market for Indian Rupee. They found that the NDF market is influenced by spot and forward markets and the volatility spillover effect exists from spot and forward markets to the NDF market. While volatility spillover is also observed in the reverse direction, its extent is marginal. Korean and Taiwanese NDF markets were extensively examined by Wang, Fawson, Chen \& Wu (2014). They found inter alia that spot, NDF, and deliverable forward markets are related to each other with price feedback effects in Korea, while in Taiwan the spot market has impact on forward markets, but the NDF market has less influence on the spot market. According to Jia, Shen, Ren \& Xu (2021), who investigated the market for renminbi (RMB), the NDF market has influence on the spot market in the event of high expectations. When the expectations are modest, there is belief that the RMB rates spot rates are likely to be stable in the future.

In this manuscript the focus is on the general overview of the NDF market. The main objective of the study is to examine the factors which have contributed to the emergence and development of the NDF market as well as analyse its size and currency composition. The structure of the paper corresponds to the above objective. The research methods employed in the paper include different kinds of analysis, mainly descriptive and comparative analysis. It was based on literature, market reports and data collected by the Bank for International Settlements (BIS).

\section{Concept of non-deliverable forwards}

Forward transactions are agreements between two parties to exchange a pair of currencies at a specific time in the future at a predetermined rate, the so-called forward rate. They are traded over the counter. NDFs are similar to regular forwards, except at maturity they do not require delivery of currencies. In the case of NDFs the only cash flow is the payment of the difference between the forward rate and the prevailing spot rate (fixing rate) on the maturity date. This compensation payment is received by the party to the contract that correctly predicted the direction of the exchange rate change. The fixing rate is usually provided by the central bank, and commonly computed as an average of rates quoted by a number of market dealers at a specified time of day. However, it should be indicated that the exact method of determining the fixing price is agreed upon the commencement of the transaction. It should be added that NDFs resemble currency futures transactions. In the case of both contracts cash 
settlement occurs instead of physical delivery of currencies. Nonetheless, there are also differences. Currency futures contracts are traded on centralised exchanges, they are standardised, while NDFs are the over-the-counter instruments, which are tailor-made to suit the requirements of the client.

The reason for emergence of NDF contracts were currency restrictions applied in some countries which prevented non-residents from accessing the local currency market. With controls imposed by local financial regulators and consequently the non-existence of a natural forward market for non-residents, private companies and investors investing in these countries looked for alternative avenues to hedge their exposure to currencies of these countries. The NDF, in which the compensation payment is paid in a convertible currency (typically in US dollars) has become such an alternative for offshore investors (Misra \& Behera, 2006; Wan, Yan \& Zeng, 2020).

As it has already been mentioned, forward transactions are conducted according to the forward rate. The calculation of the forward rate is based primarily on the theory of interest rate parity, according to which the nominal interest rate differential between two countries is equal to the difference between the forward rate and the spot rate (see Formula 1). When one of the currencies has a higher interest rate than the other, its forward rate should be lower than the spot rate. Otherwise, there would be the possibility of unlimited earnings, consisting in mass borrowing of a currency with a lower interest rate, and then investing the obtained funds in a currency with a higher interest rate. Thus, if the interest rate parity applies, the income from an equivalent investment in the international money market will be the same regardless in which currency and in which country the money is invested.

where:

$$
\frac{F}{S}=\frac{1+i_{h}}{1+i_{f}}
$$

F - forward rate,

$S$ - spot rate,

$\mathrm{i}_{\mathrm{h}}-$ onshore interest rate,

$i_{f}-$ offshore interest rate.

From the formula for the interest rate parity (1) the forward rate can be derived which will be:

$$
F=\frac{S\left(1+i_{h}\right)}{\left(1+i_{f}\right)}
$$


In addition to the elements included in the formula (2), other factors, such as market liquidity and counterparty risk, may also affect pricing of forwards contracts. ${ }^{1}$

The rate in an NDF transaction can also be affected by: the probability of a change in foreign exchange rate regime, speculative positioning, the degree of development of the local money market or the relationship between the onshore and offshore forward market. And if foreign investors have no or little access to the country's onshore deposit market, NDF rates are almost exclusively a reflection of the expected future level of the spot rate (Lipscomb, 2005). In this case, the formula for the forward rate (2) should be modified as follows (Ma, Ho \& McCauley, 2004):

$$
N D F=\frac{S\left(1+i_{N D F}\right)}{\left(1+i_{f}\right)}
$$

where:

NDF - forward rate in the NDF transaction, $\mathrm{I}_{\mathrm{NDF}}$ - the NDF-implied yield on the home currency offshore.

In the case of capital controls in the onshore market, which result in lack of full access to the onshore money market by non-residents, the implied NDF rate (the rate resulting from the quotation of the NDF contract) may be substantially different from the actual interest rate in the onshore market. This is supported by Doukas \& Zhang (2013) who studied performance of NDF carry trades. They found that the onshore-offshore interest rate differential is economically large for NDF currencies, which indicates deviations from covered interest parity in offshore markets. It should be added that large and long-lasting differences between the above-mentioned rates most often prove that foreign exchange restrictions are effective (Ma, Ho \& McCauley, 2004).

What should also be highlighted that while NDFs can be an efficient tool of hedging and speculation, they also involve a number of risks. One of them is

1 What should be indicated is that the formula (2) is simplified. It assumes an average spot rate and a uniform interest rate in the market. As a matter of fact, the forward rate in the foreign exchange market is bilateral, which means it consists of two prices: a bid rate and an offer rate. Thus, the formula for calculation of the bid forward rate includes the bid spot rate, the onshore bid interest rate and the offshore offer interest rate. And the formula for the forward offer rate includes the offer spot rate, the onshore offer interest rate and the offshore bid interest rate. The formulas for the bid and offer forwards are calculated as follows: $F_{b i d}=\frac{s_{\text {bid }}\left(1+i_{h}^{\text {bid }}\right)}{\left(1+i_{f}^{\text {offer }}\right)}, F_{\text {offer }}=\frac{s_{\text {offer }} *\left(1+i_{h}^{\text {offer }}\right)}{\left(1+i_{f}^{\text {bid }}\right)}$. The difference between the forward rate and spot rate is called swap points. 
the pre-settlement risk, which can emerge prior to the start of the settlement process. Participants of the NDF market are also exposed to the settlement risk which is the risk of lack of expected settlement in a funds transfer system (BIS, 2016). Those risks are significantly reduced thanks to establishment of central counterparty institutions (CCP). A CCP is an entity that interposes itself between the parties of a transaction, being the seller to every buyer and the buyer to every seller (BIS, 2016).

\section{Development of the NDF market}

Non-deliverable forwards started to be used in Latin America in the early 1990s. The outbreak of the financial crisis in Mexico at the end of 1994, which then spread to other Latin American countries, was of particular importance for the development of NDFs. Foreign investors who invested capital in this region of the world were afraid of the devaluation of local currencies and therefore needed a financial instrument that would protect them. It should be added that due to the fact that the countries affected by the crisis introduced a number of foreign exchange restrictions, non-residents had more difficultly accessing onshore money and currency markets and, consequently, could not carry out hedging operations in these markets. Foreign exchange restrictions were introduced because the local monetary authorities were afraid that easy access of non-residents to the local currency and the ability of easy transfer of the local currency to non-residents, contributed to speculative financial movements, greater volatility of the exchange rate and, consequently, some loss of monetary control (Higgins \& Humpage, 2005). The NDF transactions concluded in New York became a financial instrument that allowed foreign investors to hedge currency risk. As they did not require the delivery of local currency, because they were settled in US dollars and because they were concluded outside the jurisdiction of Latin American countries, they allowed to bypass any foreign exchange restrictions introduced by these countries. During this period, the highest turnover in NDF transactions was recorded in the Mexican peso, Chilean peso and Brazilian real markets.

At the beginning of the second half of the 1990s, international investors started to invest their capital in dynamically developing countries in Asia and Central and Eastern Europe, where high interest rates combined with falling inflation ensured higher profits than investments in highly developed countries. This growing interest from financial investors, along with a simultaneous 
increase in the inflow of direct investment to these countries, led to an increase in the demand for local currencies. These currencies, like the currencies of Latin American countries, were not fully convertible. In order to bypass foreign exchange restrictions, investors hedged exchange rate risk using NDF transactions. A consequence of the Asian crisis was the introduction of even stricter foreign exchange restrictions by countries affected by the crisis, which contributed to a further increase in the turnover of NDF contracts in this region of the world (Misra \& Behera, 2006).

It should be added that while initial impetus for development of the NDF market was the need for hedging, soon afterwards NDFs became also speculative instruments to take positions offshore in emerging markets currencies. NDFs allow speculation in a currency without providing or requiring funding in it. Estimates have indicated that a large proportion of NDF contracts are generated by speculative interest, especially by international hedge funds (Wang, Fawson, Chen \& Wu, 2014).

The development of NDF markets was also largely due to the entry of voice brokers into the market in the mid-1990s, which, as intermediaries, significantly increased market liquidity (Lipscomb, 2005). In 1997, the importance of NDF instruments was noticed by the International Swaps and Derivatives Association, which developed standard rules for settling these contracts (Misra \& Behera, 2006). Those templates facilitate the process of entering into and confirming NDF transactions. They provide definitions and give precise information regarding fixing rates of particular currencies. They also include terms of settling NDF contracts in case of disruption fallbacks (Emerging Markets Trade Association [EMTA], 2021).

The financial crisis of 2007-2009 was another factor that had impact on NDF markets. In the aftermath of the crisis, measures to reduce systematic risks resulting from decentralisation of derivatives markets were taken. They included promotion of trading on electronic platforms, mandatory trade reporting and centralised clearing. As a result, NDFs, as well as other derivatives have begun to shift to centralised trading platforms. Moreover, central clearing of NDFs started to be encouraged by requirement of higher margins for non-cleared NDFs. Those factors and the fact that disclosure of trades has become obligatory in a number of jurisdictions, led to increased transparency of the market (McCauley \& Shu, 2016).

Currently the NDF market is well developed. The main reason for conducting NDF contracts are still restrictions in onshore markets particularly for non-residents. They are present in most emerging market economies (EMEs). The 
motivation behind them is to reduce financial speculation, safeguard financial stability and maintain control over the currency onshore. But as the example of the Russian rouble shows, NDF market can still exist when the currency is moved to the full convertibility (Schmittmann \& Teng, 2020).

\section{Turnover in the global NDF market}

The NDF market activity has been surveyed largely every three years since 2013 by Bank for International Settlements (BIS). The BIS Triennial Central Bank Survey is the most complete source of data on the size and structure of the global NDF market. The survey involves central banks and other authorities in around 50 countries. They get data from close to 1,300 banks and other financial institutions (reporting dealers), and then report to the BIS, which aggregates them. Turnover data are provided by the sales desks of reporting institutions (BIS, 2019). Reporting dealers deliver data related to all foreign exchange (FX) market instruments (Table 1).

Table 1. Foreign exchange turnover, 2013-2019 (net-net basis, daily averages in April, in billions of US dollars)

\begin{tabular}{|l|c|c|c|}
\hline \multicolumn{1}{|c|}{ Instrument } & $\mathbf{2 0 1 3}$ & $\mathbf{2 0 1 6}$ & $\mathbf{2 0 1 9}$ \\
\hline Spot transactions & 2,047 & 1,652 & 1,987 \\
\hline Deliverable forwards & 553 & 566 & 741 \\
\hline NDFs & 127 & 134 & 259 \\
\hline Foreign exchange swaps & 2,240 & 2,378 & 3,202 \\
\hline Currency swaps & 54 & 82 & 108 \\
\hline Options and other products & 337 & 254 & 294 \\
\hline Exchange traded instruments & 145 & 115 & 127 \\
\hline
\end{tabular}

Source: own work based on BIS, 2013-2019.

OTC instruments have much higher turnover in comparison with exchange traded transactions (currency futures and exchange traded currency options). The most popular instruments of the OTC FX market are foreign exchange swaps, spot transactions and deliverable forwards. While NDFs do not attract such a big interest, it should be pointed out that since 2016, their turnover has been higher than the turnover of the exchange traded instruments (Table 1). 
Figure 1. Forward market turnover, 2013-2019 (net-net basis, daily averages in April, in millions of US dollars)

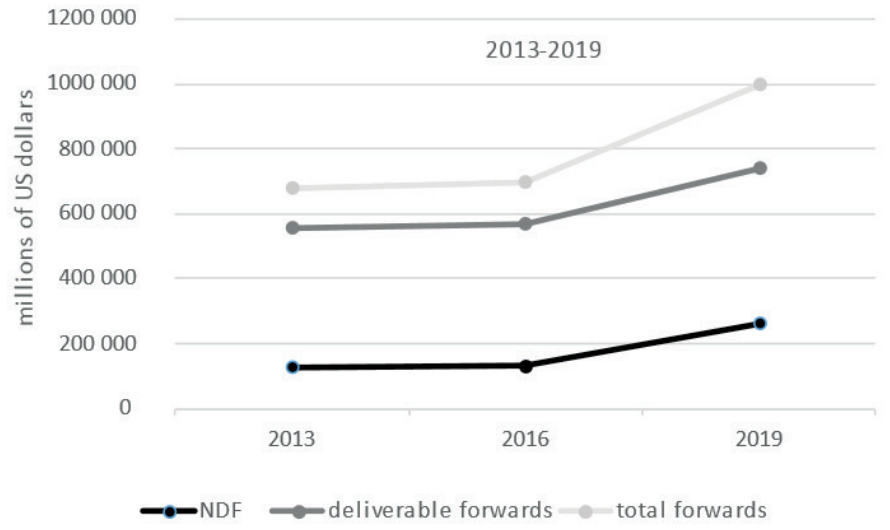

Source: own work based on BIS, 2013-2019.

Turnover in the currency forward market rose in 2019, as well as in 2016. At \$1,987,441 millions per day, the volume of forward trades in 2019 was some $20 \%$ greater than in 2016. The dynamic of growth in 2019 was higher than in 2016 when the forward market grew by $3 \%$ only (Figure 1).

Trading in deliverable forwards was more common than in NDFs, but NDFs accounted for a significant share of the increase in forward trading between 2016 and 2019 (driven in large part by increased market electronification) (Patel \& Xia, 2019). NDFs had 26\% share in forward trades in April 2019, up from $19.15 \%$ in 2016 and $18.61 \%$ in 2013 (Figure 2). The relative importance of NDFs increased significantly over the twelve-year period - NDFs represented only $2.37 \%$ of total foreign exchange turnover in 2013 , but $8.11 \%$ in 2016 , and $13.02 \%$ in 2019.

Daily turnover in the NDF market gained slightly in 2016, but the NDF trades experienced a spectacular rise of daily turnover in 2019, reflecting in particular the heavy investors activity in some currencies of emerging market economies (BIS, 2019). Trading in NDFs rose by a notable $93 \%$ to $\$ 740,528$ million per day in 2019. By contrast, at $\$ 565,665$ million per day, the volume of NDF transactions in 2016 was only 6\% greater than in 2013 (Figure 1).

The NDF market grew faster than deliverable forward trading between 2013 and 2019. While NDF trades rose by $6 \%$ in 2013, deliverable forwards experienced only $3 \%$ growth in daily turnover. There was a huge difference in 2019 when NDF trades almost doubled, and the deliverable forward market rose by $43 \%$. 
Figure 2. NDF as a part of FX market (net-net basis, daily averages in April, in per cent)

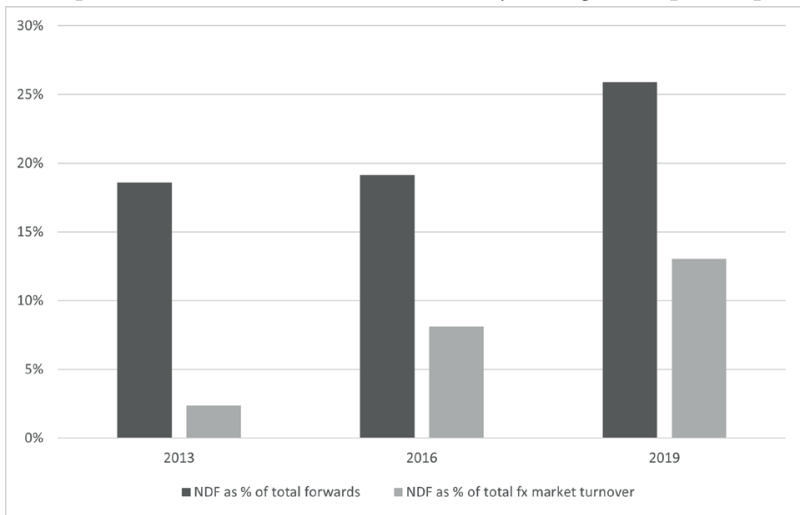

Source: own work based on BIS, 2013-2019.

The analysis of currency structure of the global NDF market enables to distinguish key currencies with large NDF markets - the Korean won (KRW), the Indian rupee (INR), the Brazilian real (BRL) and the Taiwan dollar (Figure 3). The emerging market economy currencies are used as base currencies in NDF transaction (the currencies of notional value).

Figure 3. NDF trading by currency (net-net basis, daily averages in April, in per cent)

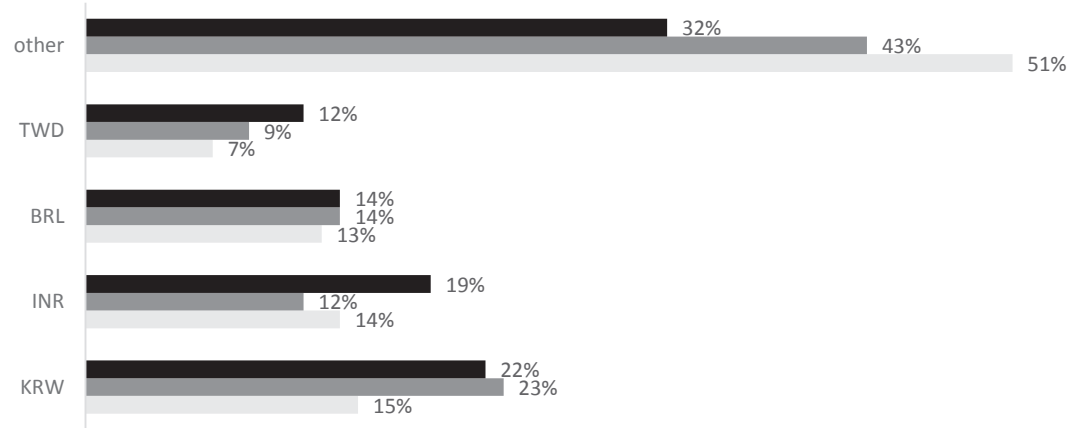

Source: own work based on Patel \& Xia, 2019.

The US dollar remained the dominant settlement currency of the NDF market market, which means that the difference between rates is paid in the US dollar (Table 2). The share of the currency rose by about 5 percentage points from 94.4\% to $99.6 \%$ of total the NDF turnover in April 2019 (Table 3). The value of settlements in US dollar rose to $\$ 257,725$ million in 2019 from $\$ 119.510$ million in 2013 and \$130,224 million in 2016, 9\% increase in 2016 and 98\% in 2019. 
Table 2. Key settlement currencies of NDF transactions - turnover by currency, 2013-2019 (total reported transactions in specified currencies, net-net basis, daily averages in April, in millions of US dollars)*

\begin{tabular}{|c|c|c|c|c|}
\hline \multirow{2}{*}{} & \multirow{2}{*}{ Total } & \multicolumn{3}{|c|}{ Specified currency against all other currencies } \\
\cline { 3 - 5 } & & USD & EUR & JPY \\
\hline $\mathbf{2 0 1 3}$ & 126,563 & 119,510 & 1,642 & 973 \\
\hline $\mathbf{2 0 1 6}$ & 134,011 & 130,224 & 1,307 & 1,420 \\
\hline $\mathbf{2 0 1 9}$ & 258,790 & 257,725 & 4,635 & 2,503 \\
\hline
\end{tabular}

* Because two currencies are involved in each transaction, the sum of transactions in individual currencies comes to twice the total reported turnover.

Source: own work based on BIS, 2013-2019.

Table 3. Key settlement currencies of NDF transactions - turnover by currency, 2013-2019 (total reported transactions in specified currencies, net-net basis, daily averages in April, in per cent $)^{*}$

\begin{tabular}{|l|c|c|c|}
\hline \multirow{2}{*}{} & \multicolumn{3}{|c|}{ Specified currency against all other currencies } \\
\cline { 2 - 4 } & USD & EUR & JPY \\
\hline 2013 & 94.4 & 1.3 & 0.8 \\
\hline 2016 & 97.2 & 1.0 & 1.1 \\
\hline 2019 & 99.6 & 1.8 & 1.0 \\
\hline
\end{tabular}

* As two currencies are involved in each transaction, the sum of shares in individual currencies will total $200 \%$.

Source: own work based on BIS, 2013-2019.

Other currencies applied by investors to calculate profit or loss from the NDF transaction are euro and Japanese yen, but their importance is much smaller (Table 3).

The value of settlements in euro, the world's second most traded currency, dropped to $\$ 1,307$ million in 2016, a 20\% decrease compared with 2013. By contrast, there was a rise in both absolute and relative terms in 2019. The value of settlements in euro gained heavily to $\$ 4,635$ million in 2019 , at a notably high rate $255 \%$ (Table 2). This reflected a higher growth than in USD and JPY.

The value of settlements in Japanese yen experienced the rise each analysed year. In 2016, at $\$ 1,420$ per day it was some $46 \%$ greater than in 2013 . There was a significant increase with the rate $76 \%$ in 2019 (Table 2).

Trading in the most popular USD cross, USD/KRW, increased significantly over the twelve-year period. In 2019, the turnover tripled relative to 2013, from 
$\$ 19.565$ million in 2013 and $\$ 30,075$ million in 2016, to \$60,103 million in 2019 (Table 4). The share of USD/KRW in NDF trading rose about 7.7 percentage points from $15.5 \%$ in 2013 to $23.2 \%$ in 2019 .

Table 4. NDF market turnover by currency pairs, 2013-2019 (net-net basis, daily averages, in millions of US dollars)

\begin{tabular}{|c|c|c|c|c|c|c|}
\hline & USD/KRW & USD/INR & USD/BRL & USD/TWD & USD/CNY & USD/RUB \\
\hline $\mathbf{2 0 1 3}$ & 19,565 & 17,204 & 15,894 & 8,856 & 17,083 & 4,118 \\
\hline $\mathbf{2 0 1 6}$ & 30,075 & 16,427 & 18,653 & 11,504 & 10,359 & 2,926 \\
\hline $\mathbf{2 0 1 9}$ & 60,103 & 50,018 & 35,746 & 30,865 & 11,768 & 5,497 \\
\hline
\end{tabular}

Source: own work based on BIS, 2013-2019.

Turnover in USD/INR, the second most traded cross, declined slightly in both absolute and relative terms in 2016. In 2016, the currency pair experienced 4.5\% decrease in total trading compared with 2013 (Table 4), with the share in global NDF turnover falling to $12.3 \%$ from $13.6 \%$ in 2013 (Table 5). By contrast, the turnover rose to $\$ 50,018$ million in 2019 , over $200 \%$ increase compared with 2016. In consequence, the cross USD/INR accounted for $19.3 \%$ of NDF turnover in 2019, 7 percentage points increase relative to 2016 .

In 2019, the third most traded currency pair of the NDF market, was a cross USD/BRL. The relative importance of the cross was stable over the twelve-year period, with the share in the global NDF market from $12.6 \%$ to some $14 \%$ (Table 5). The currency pair took the second place in global ranking in 2016, but dropped again to the third in 2019. While the volume of trades in USD/BRL pair increased significantly in 2019 relative to 2016 (with the rate 92\%), the expansion was less strong in 2016 (with the rate 17\%).

The increasing tendency touched the cross USD/TWD, and the trading in USD/TWD rose by a very high rate in every analysed year. The turnover reached $\$ 30.865$ million per day in April 2019, up from \$11,504 million in 2016, and $\$ 8,856$ million in 2013. The trading in USD/TWD increased more than the aggregate NDF market growth, and its share in the global NDF turnover edged up to almost 12\% in 2019, from 7\% in 2013 and $8.6 \%$ in 2013 .

In contrast, renminbi trades stagnated, and the share of the USD/CNY cross in the global turnover dropped by 9 percentage points, from $13.5 \%$ in 2013 to $4.5 \%$ in 2019 (Table 5). The currency pair experienced a heavy decrease in 2016, when the turnover fell by almost $40 \%$ rate. The sharp drop in turnover in the renminbi NDF was a consequence of the liberalisation of the Chinese currency (McCauley \& Shu, 2016). In 2019, the turnover in USD/CNY 
increased at a lower rate than did the aggregate NDF market (14\% growth in USD/CNY trades relative to $93 \%$ rise of the whole NDF market), so the cross lost its relevance even more.

The currency pair USD/RUB was also among the most popular crosses of the global NDF market. At \$5,497 per day, the volume of trades in 2019 was some $88 \%$ greater than in 2016, and it was the highest level over the analysed period (Table 4). The trading in USD/RUB declined heavily by $29 \%$ to $\$ 5,497$ million per day in 2016 , from $\$ 4,111$ million in 2013. In 2019, the cross reached $2.1 \%$ share in the total NDF trading, down from $3.3 \%$ in 2013 and $2.2 \%$ in 2016 .

Table 5. NDF market turnover by currency pairs, 2013-2019 (net-net basis, daily averages, in per cent)

\begin{tabular}{|c|c|c|c|c|c|c|}
\hline & USD/KRW & USD/INR & USD/BRL & USD/TWD & USD/CNY & USD/RUB \\
\hline $\mathbf{2 0 1 3}$ & 15.5 & 13.6 & 12.6 & 7.0 & 13.5 & 3.3 \\
\hline $\mathbf{2 0 1 6}$ & 22.4 & 12.3 & 13.9 & 8.6 & 7.7 & 2.2 \\
\hline $\mathbf{2 0 1 9}$ & 23.2 & 19.3 & 13.8 & 11.9 & 4.5 & 2.1 \\
\hline
\end{tabular}

Source: own work based on BIS, 2013-2019.

Apart from the six currency pairs, shown in table 4, NDF markets are active in a number of other EME currencies like the Indonesian rupiah, Malaysian ringgit, and Chilean and Colombian pesos (McCauley \& Shu, 2016).

The most active investors in the NDF market are reporting dealers and non-banking financial institutions which hedge their holdings or speculate with leverage (hedge funds, proprietary foreign exchange accounts of commercial and investment banks, multinational corporations, portfolio investors) (Ma, Ho, \& McCauley 2004).

The analysis of the NDF trading composition by counterparties and currencies is possible thanks to data collected by McCauley and Shu (2016), who based their research not only on reports prepared by BIS, but London Foreign Exchange Joint Standing Committee also. McCauley and Shu focused on the NDF trading involving five EME currencies against the US dollar. They showed the dominant role of reporting dealers in the NDF market for such currencies as the Korean won, the Indian rupee, and the renminbi (around $45-50 \%$ share), while non-bank financial firms were the key investors in BRL and RUB trading (around 45\% share) (McCauley \& Shu, 2016).

The analysis of trade location enables to indicate the offshore market as the key segment of the NDF market. In 2016, offshore NDFs, which are 
defined as trades executed outside the jurisdiction where the currency is issued, accounted for $88 \%$ of the NDF trading (including six the most liquid currencies of the NDF market). Asian currencies such as the Korean won and the Indian rupee reached the highest turnover in the NDF offshore market at the level of $\$ 22,718$ million and $\$ 16,427$ million, respectively (McCauley \& Shu, 2016). The NDF trading is concentrated in the main FX hubs, especially in the United Kingdom ( $46 \%$ share in 2019), which significantly gained importance, in contrast to the United States and Asian financial centres. Singapore experienced the sharp drop in the share of the NDF trading (from $26 \%$ in 2016 to $16 \%$ in 2019) and Hong Kong also (4 percentage points drop, to $10 \%$ in 2019) (Patel \& Xia, 2019).

\section{Conclusions}

NDFs experienced a rise in the foreign exchange market share - the transactions represented only $2.37 \%$ of the total FX turnover in 2013, but $13.02 \%$ in 2019. NDFs were mainly responsible for increase in forward trading between 2016 and 2019 and its share in the forward market rose significantly from $19.15 \%$ in 2016 to $26 \%$ in 2019. The rise was caused in a large part by heavy NDF market electronification. Trading in NDFs increased over three years by spectacular $93 \%$ to $\$ 740,528$ million per day in 2019 because of the investors' activity in some currencies of emerging market economies like Korean won, Indian rupee, the Brazilian real and the Taiwan dollar. The relative importance of these four currencies increased significantly over the twelve-year period - they represented $49 \%$ of the total NDF turnover in 2013, but 57\% in 2016, and 68\% in 2019. NDF trading was more and more focused on some EME currencies, especially from Asia.

The most popular currency pairs in NDF transactions are crosses involving US dollar. Other currencies applied by investors as a settlement currency of the NDF transaction are euro and Japanese yen, but their importance is much smaller. The NDF market consists of onshore and offshore segments, but offshore trades have a dominant role, because trading offshore allows to bypass local foreign exchange restrictions which are different in particular countries. The approach to NDFs by policymakers is also different. In Korea, domestic financial institutions can invest on the NDF market, but it is not possible in Malaysia. Indonesia decided on a domestic local currency settled NDF while China has an offshore deliverable renminbi $(\mathrm{CNH})$ market (Schmittmann \& Teng, 2020). 
The NDF market is the most attractive for financial investors among which there are huge and smaller banks, but non-banking institutions also (e.g. hedge funds).

The NDF market is characterised not only by currency concentration, but geographical also. The main NDF hub is the United Kingdom. And the share of London in the NDF trading rose over three years by about 26 percentage points to $46 \%$ in 2019, continuing the trend observed since 2013.

\section{Bibliography}

Bank for International Settlements. (2013). Triennial Central Bank Survey Global foreign exchange market turnover in 2013. Retrieved from https://www.bis.org/publ/ rpfxfl3fxt.pdf (20.06.2021).

Bank for International Settlements. (2016). Glossary. Retrieved from https://www.bis. org/cpmi/publ/d00b.htm (08.09.2021).

Bank for International Settlements. (2016). Triennial Central Bank Survey Global foreign exchange market turnover in 2016. Retrieved from https://www.bis.org/publ/ rpfxfl6fxt.pdf (20.06.2021).

Bank for International Settlements. (2019). Triennial Central Bank Survey Foreign exchange turnover in April 2019. Retrieved from https://www.bis.org/statistics/ rpfx19_fx.pdf (20.06.2021).

Bank for International Settlements. (2019). Triennial Central Bank Survey Global foreign exchange market turnover in 2019. Retrieved from https://www.bis.org/statistics/ rpfx19_fx_annex.pdf (20.06.2021).

Bartram, S.M. (2019). Corporate hedging and speculation with derivatives. Journal of Corporate Finance, 57, 9-34, https://doi.org/10.1016/j.jcorpfin.2017.09.023

Campbell, J.L., Mauler, L.M. \& Pierce, S. (2019). A review of derivatives research in accounting and suggestions for future work. Journal of Accounting Literature, 42, 44-60, https://doi.org/10.1016/j.acclit.2019.02.001

Doukas, J.A. \& Zhang, H. (2013). The performance of NDF carry trades. Journal of International Money and Finance, 36, 172-190, http://dx.doi.org/10.1016/j.jimonfin.2013.04.003

Emerging Markets Trade Association. (2021). FX and Currency Derivatives Documentation. Retrieved from https://www.emta.org/documentation/emta-standard-documentation/fx-and-currency-derivatives-documentation/ (07.09.2021).

Higgins, P. \& Humpage, O.F. (2005). Nondeliverable forwards: can we tell where the renminbi is headed? Federal Reserve Bank of Cleveland, September 1. 
Jia, F., Shen, Y., Ren, J. \& Xu, X. (2021). The impact of offshore exchange rate expectations on onshore exchange rates: The case of Chinese RMB. North American Journal of Economics and Finance, 56, https://doi.org/10.1016/j.najef.2020.101349

Lipscomb, L. (2005). An Overview of Non-Deliverable Foreign Exchange Forward Markets. Federal Reserve Bank of New York, May. Retrieved from https://www. bis.org/publ/cgfs22fedny5.pdf (12.04.2021).

Ma, G., Ho, C. \& McCauley, R.N. (2004). The markets for non-deliverable forwards in Asian currencies. BIS Quarterly Review, June, 81-94.

McCauley, R. N. \& Shu, Ch. (2016). Non-deliverable forwards: impact of currency internationalisation and derivatives reform. BIS Quarterly Review, December, 81-93.

Misra, S. \& Behera, H. (2006). Non deliverable foreign exchange forward market: an overview. Reserve Bank of India Occasional Papers, 27(3), 25-55.

Patel, N. \& Xia, D. (2019). Offshore markets drive trading of emerging market currencies. BIS Quarterly Review, December, 53-67.

Schmittmann, J.M. \& Teng, C.H. (2020). Offshore currency markets: non-deliverable forwards (NDFs) in Asia. IMF Working Paper, WP/20/179.

Wan, X., Yan, Y. \& Zeng Z. (2020). Exchange rate regimes and market integration: evidence from the dynamic relations between renminbi onshore and offshore markets. North American Journal of Economics and Finance, 52, https://doi. org/10.1016/j.najef.2020.101173

Wang, K.L., Fawson, C., Chen, M.L. \& Wu, A.C. (2014). Characterizing information flows among spot, deliverable forward and non-deliverable forward exchange rate markets: a cross-country comparison. Pacific-Basin Finance Journal, 27, 115-137, https://doi.org/10.1016/j.pacfin.2014.01.002

\section{Summary}

Forward transactions are agreements between two parties to exchange a pair of currencies at a specific time in the future at a predetermined rate, the so-called forward rate. Non-deliverable forward (NDF) contracts are similar to regular forwards, except at maturity they do not require delivery of currencies. In the case of NDFs the only cash flow is the payment of the difference between the forward rate and the prevailing spot rate on the maturity date. The main objective of the study is to examine the factors which have contributed to the emergence and development of the NDF market as well as analyse its size and currency composition. The study, based on BIS surveys, leads to the following conclusions. NDFs market grew quickly over the period from 2013 to 2019, and the transactions reached $13.02 \%$ share of the total FX turnover in 2019. There was a spectacular $93 \%$ rise of the market especially in 2019 caused in a large part by heavy NDF market electronification. The Korean won, the Indian rupee, the Brazilian real and the Taiwan dollar are the main currencies of trades (68\% share in 2019), and the relative 
importance of these currencies increased significantly over the twelve-year period. The main reason for the emergence and growing interest in those NDF contracts were currency restrictions which prevented non-residents from accessing the local currency markets.

KEYwORDS: non-deliverable forward, NDF, offshore market, currency restrictions, foreign exchange market.

\section{Streszczenie}

Transakcja terminowa to umowa pomiędzy dwoma stronami na zakup lub sprzedaż określonej ilości waluty w ustalonym terminie w przyszłości po z góry określonym kursie, tzw. kursie terminowym. Nierzeczywiste transakcje terminowe (non-deliverable forward - NDF) są podobne do zwykłych kontraktów forward, jednakże w terminie zapadalności nie wymagają dostawy walut. W przypadku transakcji NDF jedynym przepływem pieniężnym jest płatność różnicy pomiędzy kursem terminowym a bieżącym kursem rynkowym w dniu zapadalności kontraktu. Głównym celem artykułu jest zbadanie czynników, które przyczyniły się do powstania i rozwoju rynku NDF, oraz analiza jego wielkości i struktury walutowej. Badanie rynku, przeprowadzone w oparciu o dane zebrane przez BIS, prowadzi do następujących wniosków. Rynek transakcji NDF rozwijał się bardzo szybko w latach 2013-2019 i w konsekwencji operacje forward bez fizycznej dostawy osiągnęły 13,02\% udział w rynku walutowym w 2019 r. Do niezwykle dynamicznego wzrostu aktywności inwestorów, powodowanego zjawiskiem elektronizacji procesu przeprowadzania transakcji, doszło zwłaszcza w 2019 r. W strukturze walutowej globalnego rynku NDF dominują takie waluty jak koreański won, indyjska rupia, brazylijski real oraz tajwański dolar, które były odpowiedzialne za $68 \%$ wszystkich operacji NDF w 2019 r. Koncentracja inwestorów na handlu tymi walutami systematycznie rosła w latach 2013-2019. Główną przyczyną pojawienia się i rosnącego zainteresowania inwestorów kontraktami NDF były ograniczenia walutowe stosowane w niektórych krajach, które uniemożliwiały nierezydentom dostęp do lokalnych rynków walutowych.

SŁowA KLUCzowE: nierzeczywista transakcja terminowa, NDF, rynek offshore, ograniczenia walutowe, rynek walutowy.

\section{Noty o autorach}

Iwona Sobol - dr hab., Faculty of Economics, University of Gdańsk; areas of specialisation: financial markets, Islamic banking and finance, international trade finance; e-mail: iwona.sobol@ug.edu.pl; ORCID: 0000-0001-6398-6266.

Monika Szmelter - dr, Faculty of Economics, University of Gdańsk; areas of specialisation: financial markets, banking; e-mail: monika.szmelter@ug.edu.pl; ORCID: 0000-0003-0712-8528. 